\title{
Relative SEA LEVEL Rise EFFECTS AT THE MARAMbaia BARRIER ISLAND AND Guaratiba Mangrove: SEPETIBA BAy (SE Brazil)
}

\section{Carolina Santana da Costa Santos ${ }^{1}$, Fábio Ferreira Dias ${ }^{1,2,4 *}$, Barbara Franz ${ }^{2}$, Paulo Roberto Alves dos Santos ${ }^{2}$, Thalita da Fonseca Rodrigues 3 , RUAN VARGas ${ }^{4}$, CAMIla AmÉrico dos SANTOS ${ }^{4}$}

1 Universidade Federal Fluminense, Marine Biology Department, Postgraduate Program in Marine Biology and coastal environments. Outeiro São João Batista, s/nº, Niterói, Rio de Janeiro, Brazil

2 Universidade Federal Fluminense, Geoenvironment Analysis Department. Avenida Litorânea, s/n-Boa Viagem, Niterói, Rio de Janeiro, Brazil

3 Universidade Federal do Rio de Janeiro, Geography Department, Postgraduate Program in Geography (Master). Athos da Silveira Ramos, $n^{\circ} 274$, Cidade Universitária, Rio de Janeiro, Brazil

4 Univeridade Federal Fluminense, Engineering, Biosystems Engineering (Master), Passo da Pátria, nº 156, São Domingos, Niterói, Rio de Janeiro, Brazil

*Corresponding AUthor, fabioferreiradias@id.uff.br

\author{
Received on 4 June 2019 \\ Received in revised form on 25 July 2019 \\ Accepted on 27 July 2019 \\ Editor: Maria Virginia Alves Martins, Universidade do Estado do Rio de Janeiro
}

\section{Citation:}

Costa Santos, C.S., Dias, F.F., Franz, B., Santos, P.R., Rodrigues, T., Vargas, R., Américo dos Santos, C., 2019. Relative Sea Level Rise Effects at the Marambaia Barrier Island and Guaratiba Mangrove: Sepetiba Bay (SE Brazil). Journal of Sedimentary Environments, 4 (3): 249-262.

\section{Abstract}

Human activities change coastal ecosystems, but they are also altered by natural causes, such as the relative sea level rise. This work analyzes the influence of changes of the relative sea level at Guaratiba mangrove and Marambaia barrier island, in Sepetiba Bay, Rio de Janeiro State (SE, Brazil), based on photo interpretation. The objective of this study is to analyze the morphodynamics of Marambaia coastal sand barrier, estimating the rate of the shoreline change by mapping the vegetation line position, variations of dune extension and overwash processes. The Marambaia barrier island and Guaratiba mangrove are highly vulnerable to sea level rise. The mangrove is suffering pressure from the relative sea level rising and urbanization. The mangrove migration towards the continent is evident through the analyses of aerial images from 1976 to 2005. If the current

\section{Introduction}

The Intergovernmental Panel on Climate Change (IPCC) has estimated that the thermal expansion of the oceans and melting glaciers were dominant factors that contributed to the sea level rise in the $20^{\text {th }}$ century (Church et al., 2013). Since 1971, studies indicate that the thermal expansion of the oceans and melting glaciers explain $75 \%$ of the observed increase (Church et al., 2013). After the $21^{\text {st }}$ century, the sea level should have a strong regional pattern change, with erosion process continues in the Marambaia barrier island, a disruption in the central area of the sand bank should occur, which will create a new communication between Sepetiba Bay and the ocean. This break will change the present internal circulation of the bay and modify the ecosystems. Also considering the anthropic pressure, if the Marambaia barrier island breaks, the mangrove area will be reduced or disappear. The sea level rise and the sedimentation rate lowering will result in the migration and marine transgression in Marambaia barrier island and Guaratiba mangrove.

Keywords: Barrier Island. Mangrove. Relative Sea Level Rise. Coastal Erosion. Overwash.

some places experiencing significant local and regional sea level differences from the global average (Church et al., 2013).

In 2007, the IPCC projected a global sea level rise of 18 $\mathrm{cm}$ to $59 \mathrm{~cm}$ for the years 1990 to 2090 . Throughout the $20^{\text {th }}$ century, the rate of sea level rise has tripled in response to the increase of $0.8^{\circ} \mathrm{C}$ of the global temperature. Since the beginning of the measurements, sea level raised $3.4 \mathrm{~mm}$ per year, which is higher than the average estimated by the IPCC of $1.9 \mathrm{~mm}$ per year. 


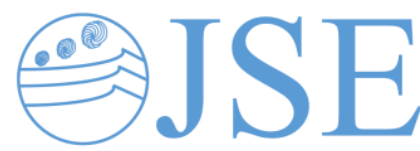

RESEARCH PAPER

Coastal areas are suffering from erosion and ecosystems loss, but few studies have observed the relationship between coastal line retreat and the sea level rise (Nicholls et al., 2007). Shoreline evolution due to natural and humaninduced causes can be variable over a wide range of different temporal and spatial scales (Stive, 2002). Changes in relative sea level triggers a series of consequences that affects directly or indirectly flooding processes, increased erosion and salt water intrusion in estuaries and aquifers, resulting in coastal ecosystems changes. The sea level rise would cause a migration of the coastal sand barriers and the mangroves towards the mainland, reducing the width of the coastal sand barrier, falling the elevation of the dunes, increasing the overwash and causing the disruption of barrier sandbanks (Gornitz, 1991). There are currently three possible causes of coastal erosion, human activities, sea level rise and changes in strength and frequency of storm events, which are also being influence by anthropic activities (Zhang et al., 2004; van Rijn, 2011).

Due to anthropogenic pressure, coastal areas also have environmental problems caused by pollution, coastal erosion, dunes degradation, saline water intrusion into the aquifers and rivers. Coastal areas are associated with climatic factors (wind and variations of sea level), oceanographic factors (waves and tides activity), geological factors (sediment budget) and anthropogenic factors. These factors influence the erosion processes, the deposition and/or removal of sediments and sediment transport in coastal areas (Souza, 2009), involving the beach sedimentary balance.

The sedimentary balance of a beach results of the relationship between losses and gains of sediment (Fig. 1). The sediment exchange occurs between the beach and the mainland or between the continental shelf and the beach (Bird, 2008; Souza, 2009; Davidson-Arnott, 2010) The removal of sand from beaches by man or artificial nourishment also influence the sediment budget. When the balance is negative, namely sediment loss is greater than the gain, there is a deficit and sediment erosion and retrogradation of the shoreline. On the contrary, when the balance is positive, there are sediment gain for the deposits and progradation of the shoreline. When the balance is zero, the beach system reaches the stability (Souza, 2009).

Sea-level rise is not a unique process causing shoreline change: instead, numerous factors and processes acting at different spatial and timescales are involved causing shoreline changes (Fig. 2; Cozannet et al., 2014). Several types of coastal systems are not expected to respond similarly to the same rates of sea-level change (Cozannet et al., 2014). Because of the multiplicity of factors, processes, interactions and feedbacks and so the attribution of shoreline changes to one or several causes is complex and difficult (Bird, 1996; Stive, 2004; Garcin et al., 2011; Cozannet et al., 2014 and references herein).

Dune fields are the major sink of sediments along the Brazilian coast, resulting from the huge transfer of beach sediments to the inland, removing sediments that are part of the balance of the beach-shore face system (Neves and Muehe, 2008). According to Ponçano and Fulfaro (1976), dunes are formed due to wind transport of sediments, indicating a possible migration of the barrier due to the availability of sediment.

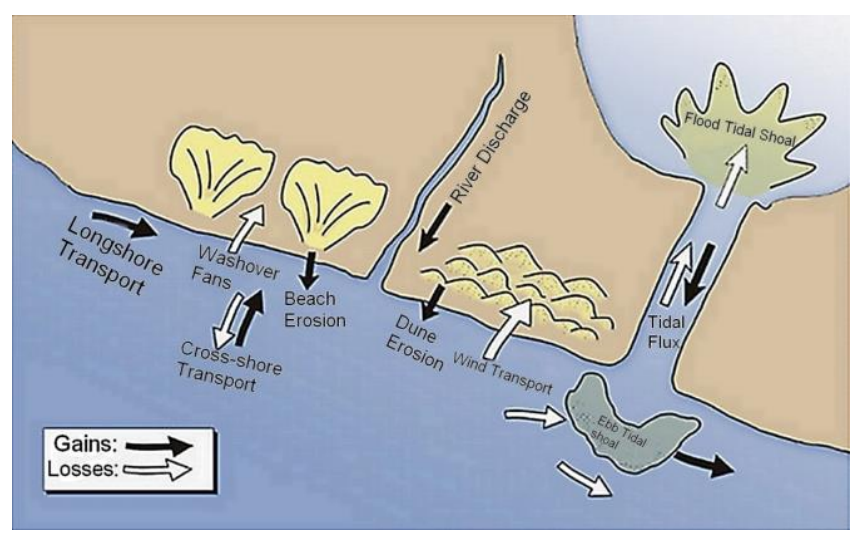

Fig. 1. Sedimentary budget in the coastal zone (Komar,1996; NOAA, 2016).

The barrier islands are changing constantly. These changes are influenced by the following conditions (Freudenrich, 2001):

a) Waves: Waves continually deposit and remove sediments from the ocean side of the island.

b) Currents: Longshore currents that are caused by waves when they reach the island at an angle can move the sand from one end of the island to another. For example, the offshore currents along the east coast of the United States tend to remove sand from the northern ends of barrier island and deposit it at the southern ends.

c) Tides: The tides move sediments into the saltmarshes. Thus, the southern sides of barrier islands tend to build up as the ocean sides erode.

d) Winds: Winds blow sediments from the beaches, and help to form dunes, and into the marshes, which contributes to their build up.

e) Sea level changes: Sea level rising tend to push the barrier islands toward the main land.

f) Storms: Hurricanes and other storms have the most dramatic effects on barrier islands by creating overwashes and eroding beaches as well as other portions of barrier islands.

NOAA (National Oceanic and Atmospheric Administration) (2019) provides a sea level rise rate of 2.24 $\mathrm{mm} /$ year for Rio de Janeiro city (at Fiscal Island), based on monthly mean sea level data from 1963 to 2016. With this local rate of sea level rise, mangroves may retreat towards the continent. However, if sea level exceeds mangrove migration capacity, which is already close to physical barriers such as urban construction, agricultural fields or mountain elevations, its area will become much smaller (Kjerfve and 
Macintosh, 1997). In case of events of extreme weather conditions, there would be a significant change in the morphology of the coastal barrier island due to large sediment transport resulting from the force of waves and currents and consequently the destruction of the protective vegetation and dunes (Vargas et al., 2008). The sea level rise will intensify this environmental stress causing coastal flooding in low zones, beach erosion and destruction of coastal areas (Snoussi et al., 2009).

Engineering works performed in Sepetiba harbor, which was designed in 1982 to become the Industrial and Port Complex of Itaguaí, also changes the natural sedimentary dynamic. In addition, these interventions also generated environmental conflicts in the area, since they consisted in the construction for a general cargo terminal, which required
RESEARCH PAPER

the grounding of an area near the coast. For this ground were taken 20 million cubic meters of Sepetiba Bay bottom material. The applied dredged material used in the landfill had high degree of both organic and inorganic pollution which generated big problems. Among the expansion works, dredging works for the sinking of the Sepetiba Bay entrance channel were carried out. These works revolved sediments and also the metal waste released in this transitional system during several decades, already accumulated in subsurface bottom sediments in Sepetiba Bay (Díaz Morales et al., 2019, and references herein). This dredging for the sinking of the navigation channel to 14-17.5 meters (Portos Rio, 2010) removed 5 million cubic meters of sediments from the bay bottom, generating pollution and siltation of other areas (Bastos and Bassani, 2012).

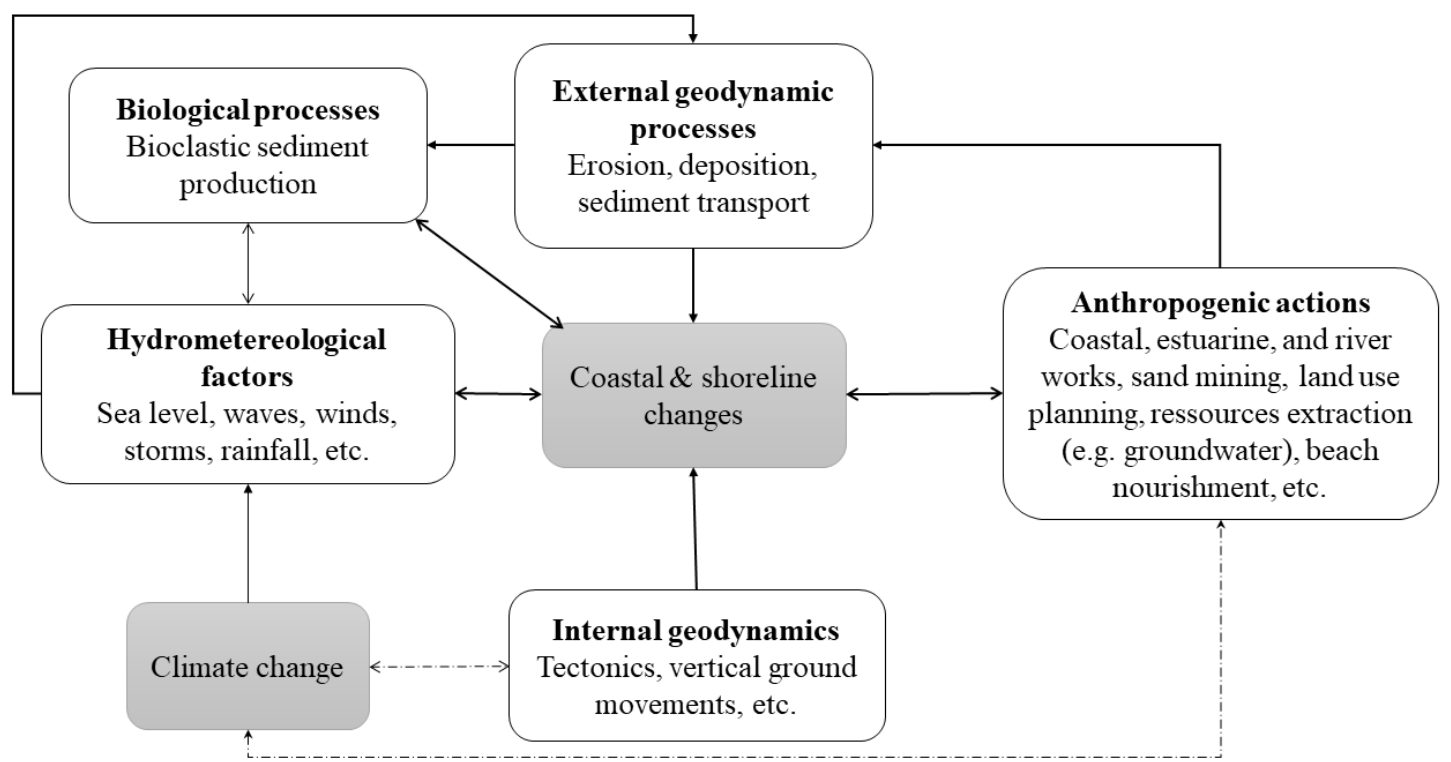

Fig. 2. Different categories of factors and processes involved in shoreline changes. Interactions and feedbacks between these factors are indicated by arrows. Because of the multiplicity of factors, processes, interactions and feedbacks, the attribution of shoreline changes to one or several causes is complex and difficult (Bird, 1996; Stive, 2004; Garcin et al., 2011; Cozannet et al., 2014).

The objective of this study is to analyze the morphodynamics of Marambaia coastal sand barrier in Rio de Janeiro State, estimating the rate of the shoreline change by mapping the vegetation line position, dune extension and by detecting the occurrence overwash processes.

\section{2 - Study Area}

Marambaia barrier island and Guaratiba mangrove are included in Sepetiba Bay, Rio de Janeiro State (Fig.3). The Guaratiba Biological Reserve (RBG) has approximately 3.360 hectares and protects a remaining mangrove (INEA, 2015). Marambaia barrier island has a length of approximately $40 \mathrm{~km}$ and an area of $79 \mathrm{~km}^{2}$ (Oliveira et al.,
2008). It is separated from the main land by the "Canal do Bacalhau" (Codfish Channel) in Guaratiba and is partly located in the West Zone of the Rio de Janeiro city and in Itaguaí and Mangaratiba cities. The Marambaia barrier island is dominated by parabolic dune fields and is limited to the east by channels in Guaratiba and west plains of low and small lagoons (Ponçano and Fulfaro, 1976). The Marambaia barrier island is controlled by the Brazilian army and navy. The access to this barrier island is restrictive and requires permission of the army to get in. Because of that, it is an unpopulated area and is a protected ecosystem. In contrast, the Guaratiba mangrove is bordered by a highly urbanized, continuously growing area that negatively impacts the mangrove ecosystem. 


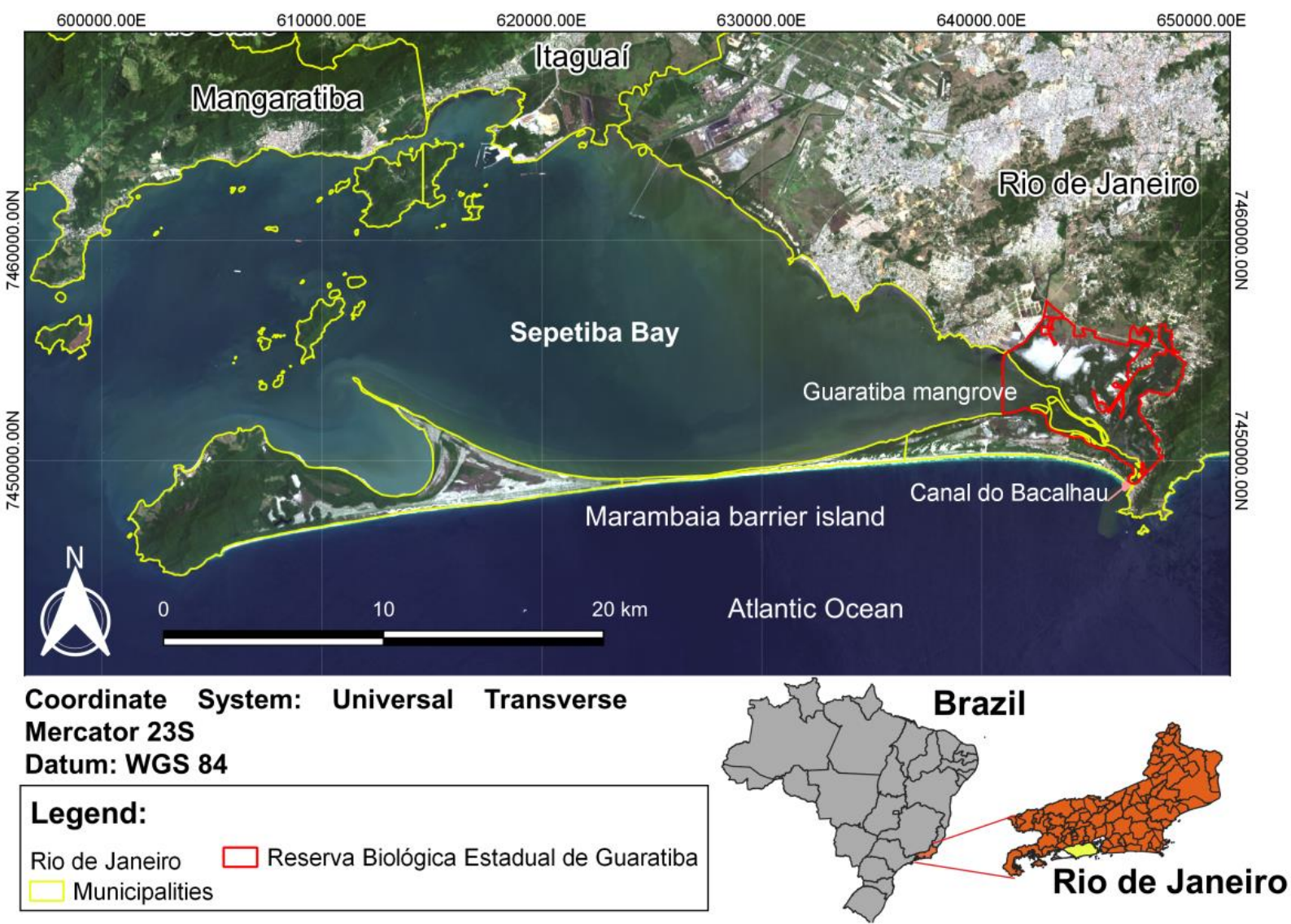

Fig. 3. Localization map. Sepetiba Bay-RJ, Marambaia Barrier Island and Guaratiba Mangrove.

\section{3-Materials and Methods}

\section{1-Materials}

The analysis of variation in the vegetation and in the shoreline, position was observed through aerial images, satellite images and orthophoto images. The source of those images is presented in table1.They were processed in Arcgis10 software producing maps in which was possible to identify the position of vegetation and shoreline change rate along 29 years - 1976, 2005 and 2015.

\section{2- Shoreline Change Rate}

According to Bush et al. (1999) there are geoindicators of coastal risk that can be used as qualitative checklist to be considered as identifying erosion and shoreline changes in coastal areas like vegetation, overwash, dune configuration, erosion rate, etc. The values are established for typical southeastern US barrier islands. So, in this study, it will be used to identify areas with erosion problems.

Aerial photographs from 1976 and orthophoto from 2005 were used to analyze vegetation migration. The first step was to import the images to the Arcgis10 and geo reference the aerial photograph images using as reference the orthophotomosaic from 2005 in WGS-84 UTM projection fuse $23 \mathrm{~S}$ zone $\mathrm{K}$. After georeferencing, it was created a line shapefile for each image and through visual criteria defining vegetation lines and saltmarsh lines. The areas with dead vegetation is one of the indicators of sea level rises and salt water intrusion, as indicated by Williams (2013).

The focus of this study in the central area of the Marambaia barrier island is similar to previous studies, such as performed by Oliveira et al. (2008), that indicated this area as the most vulnerable due to intensive erosion problems.

To calculate the shoreline change rates in the barrier island and in the mangrove, the vegetation lines in the mangrove and the barrier island were compared. Line shapefiles of 1976 and 2005 were created in the mangrove saltmarsh and shoreline vegetation and in the barrier island in both sides, the Atlantic Ocean and Sepetiba Bay. Then, polygons equivalent to the area between the shoreline position in 1976 and 2005 were created. The determination of the shoreline change rates (SCR) were calculated dividing the obtained balance (SD) between the accretion area (AA) and eroded area (EA) divided by extension of the coastline (ECL) of 1976 (Almeida et al., 2013). 


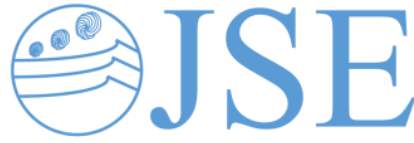

RESEARCH PAPER

Tab. 1. Data used for the analysis of the long-term shoreline changes.

\begin{tabular}{|c|c|c|c|c|}
\hline Sites & Date & Type of Document & Scale & Source \\
\hline Marambaia Barrier Island and & 1976 & Aerial photographs & $1: 10.000$ & Fundrem \\
\hline Guaratiba Mangrove & 2005 & Orthophotos & $1: 25.000$ & IBGE \\
& 2015 & Satellite image & $1: 20.000$ & Google Earth \\
\hline
\end{tabular}

$$
\begin{aligned}
\mathrm{SD} & =\mathrm{AA}-\mathrm{EA} \\
\mathrm{SCR} & =\mathrm{SD} / \mathrm{ECL}
\end{aligned}
$$

The shoreline was divided in four areas:

1- Barrier island shoreline in Sepetiba Bay

2- Barrier island shoreline in Atlantic Ocean

3- Mangrove shoreline in Sepetiba Bay

4- Mangrove saltmarsh.

\subsection{Dunes and overwash}

One indicator of shoreline erosion is the overwash (Fig.4). Overwash is a natural storm-related process that occurs when wave run up over comes the dune crest (Rodrigues et al., 2012). Brantley et al. (2014) studied specific overwash sites and classified overwash features as "active overwash" if they lacked relief and exhibited evidences of recent overwash in the past 1-2 years. Recently disturbed sites that showed some dune accretions in the most recent overwash event were classified as "intermediate overwash". Sites exhibiting evidence of overwash in the past several decades, but which were protected from wave action by seaward dunes at the time of the field survey were classified as "relict overwash".

The orthophoto images from 2005 were photo interpreted based on the work Matias et al. (2009) aiming to analyze the extent of the overwash zone in the Marambaia barrier island, by defining line shapefiles in the morphologic shapes.

Gutierrez et al. (2007) suggested some indicators to notice when a barrier island is close to the tipping point: increased rate of landward migration of the barrier, decreased barrier width and elevation of barrier and sand dunes, increased frequency of storm overwash, increased frequency of barrier breach, inlet formation and widening and segmentation of the barrier.

Coastal dunes are natural barriers protecting areas along many of the world's sandy coastlines against storm surge and wave action. The dune may erode rapidly and the lowering of the dune crest may lead to an increase in wave over topping and overwash. Overwash occurs either by inundation of the dune due to high surge and tide levels or by excessive wave run up (Figlus et al., 2011).

Field dunes (Fig. 5) are isolated masses of sand moving, that present transversal orientation towards the wind, with line ridges (transversal dunes), in half moon (barchans) or sinuous (barchans or barcanoides chains). Parabolic dunes are characterized by a $\mathrm{U}$ or $\mathrm{V}$ geometry, more or less closed with the convexity to the leeward (Almeida and Suguio, 2012).

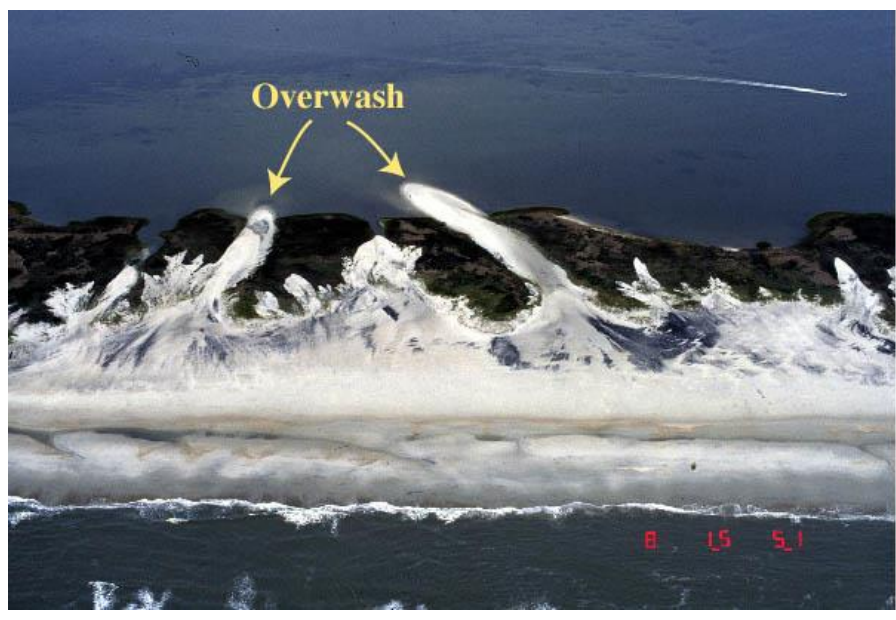

Fig. 4. Example of overwash. From: http://coastal.er.usgs.gov/ hurricanes/impact-scale/overwash.php

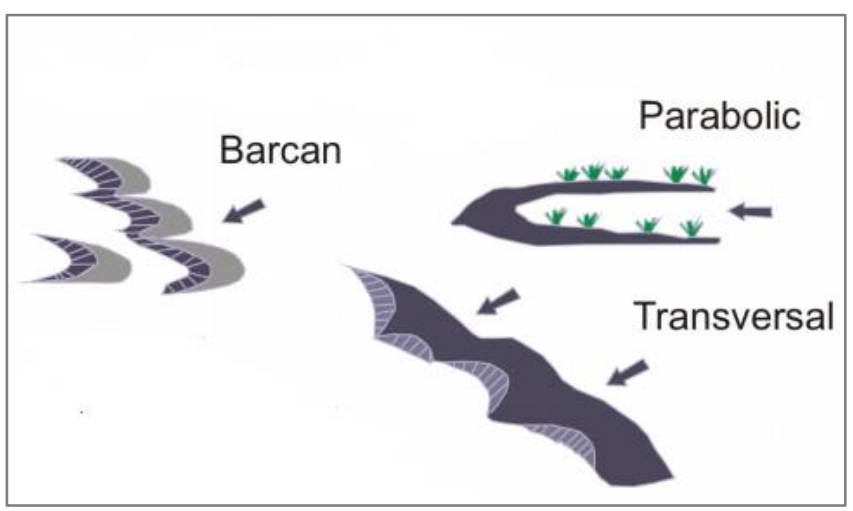

Fig. 5. Dunes morphology and its guide lines in relation to the direction of the prevailing winds (Almeida and Suguio, 2012).

\section{4 - Results and discussion}

\subsection{Shoreline change rate}

Changes in the shoreline of the Marambaia Barrier Island and in the saltmarsh area of Guaratiba mangrove were observed from 1976 to 2005, as well as a difference between the vegetation line (Figs. 6 to 8 ). 


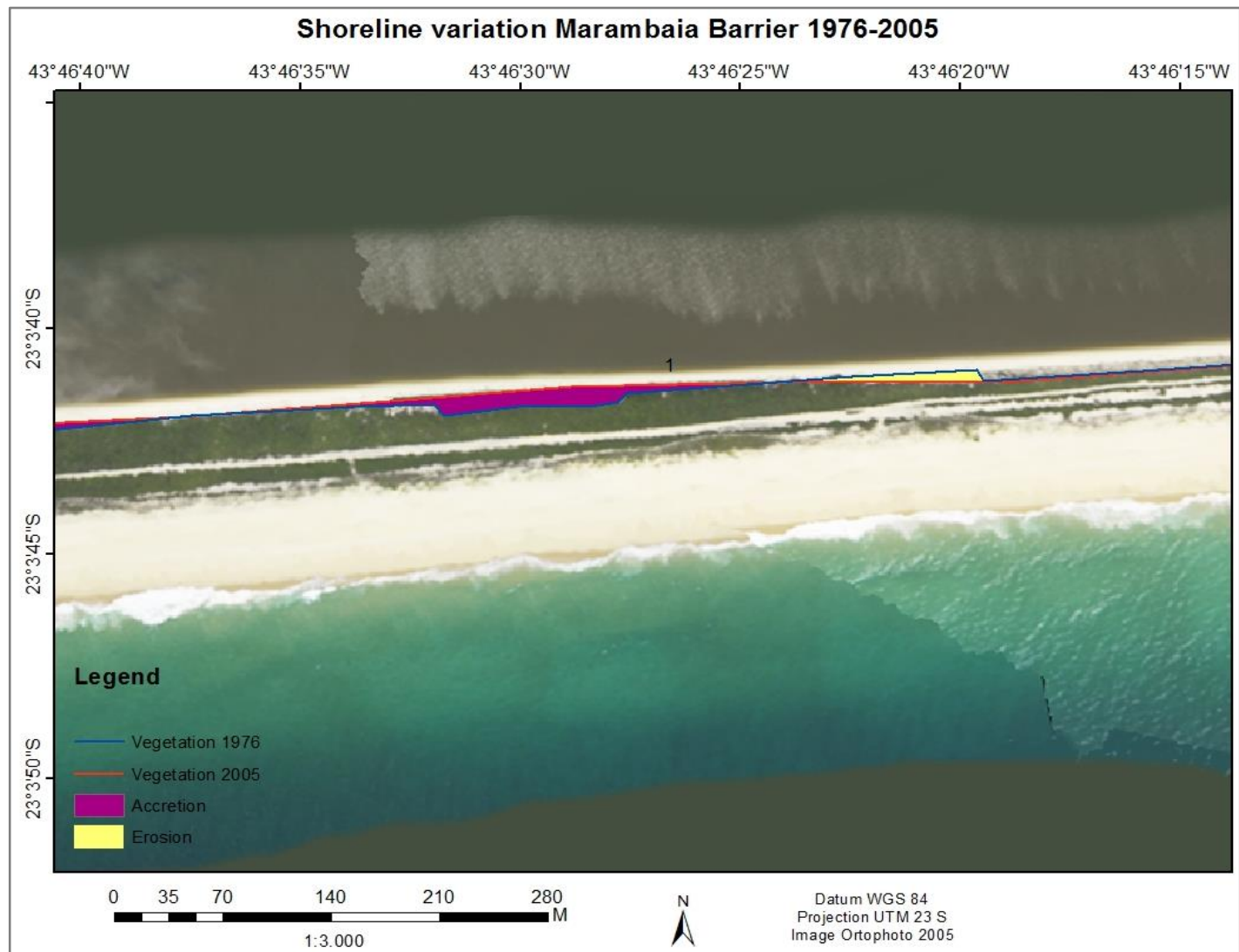

Fig. 6. Shoreline change barrier and Sepetiba Bay from 1976 to 2005. Blue line 1976, red line 2005. Pink polygon accretion and yellow polygon erosion.

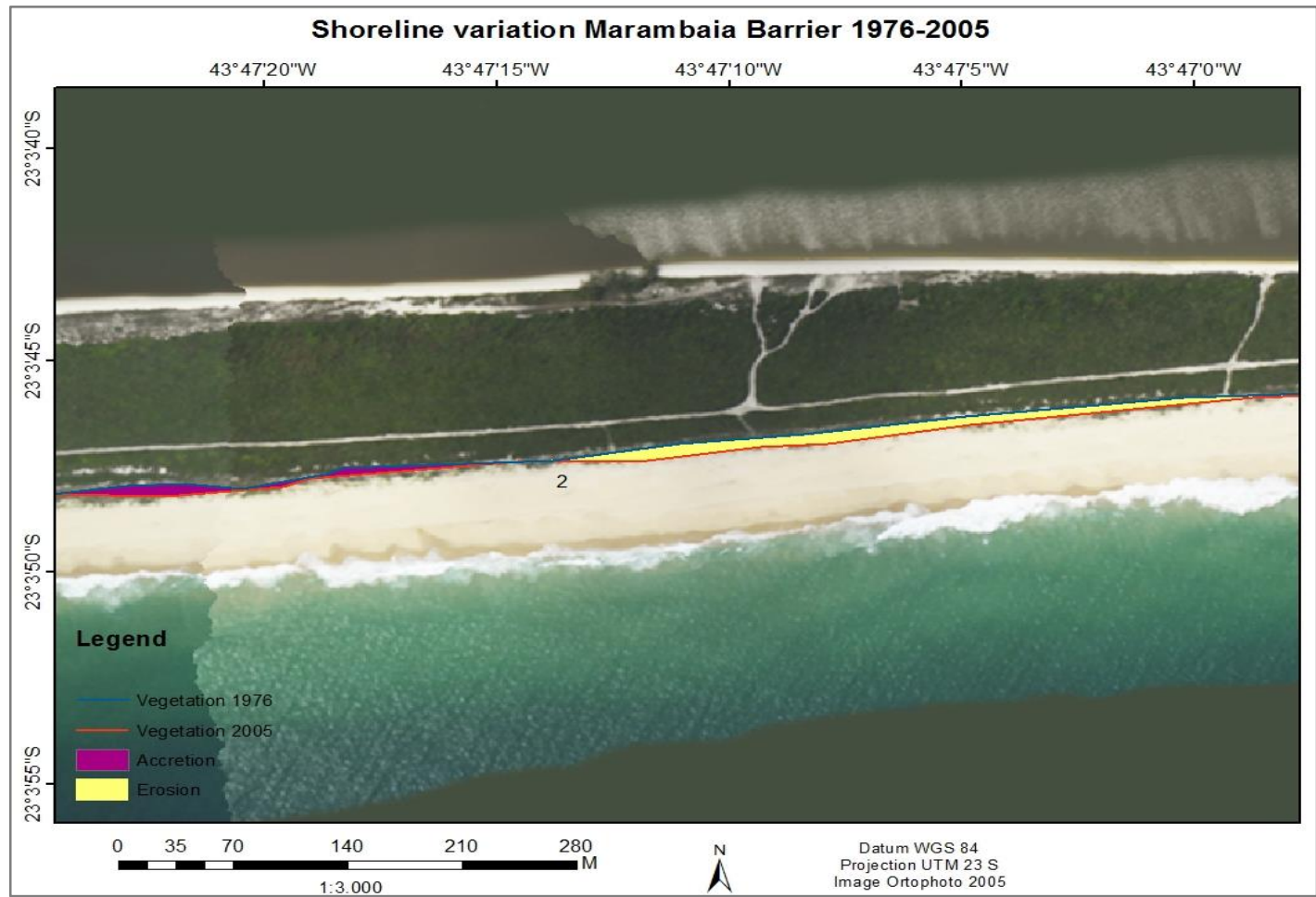

Fig. 7. Shoreline change barrier and Atlantic Ocean from 1976 to 2005. Blue line 1976, red line 2005. Pink polygon accretion and yellow polygon erosion. 


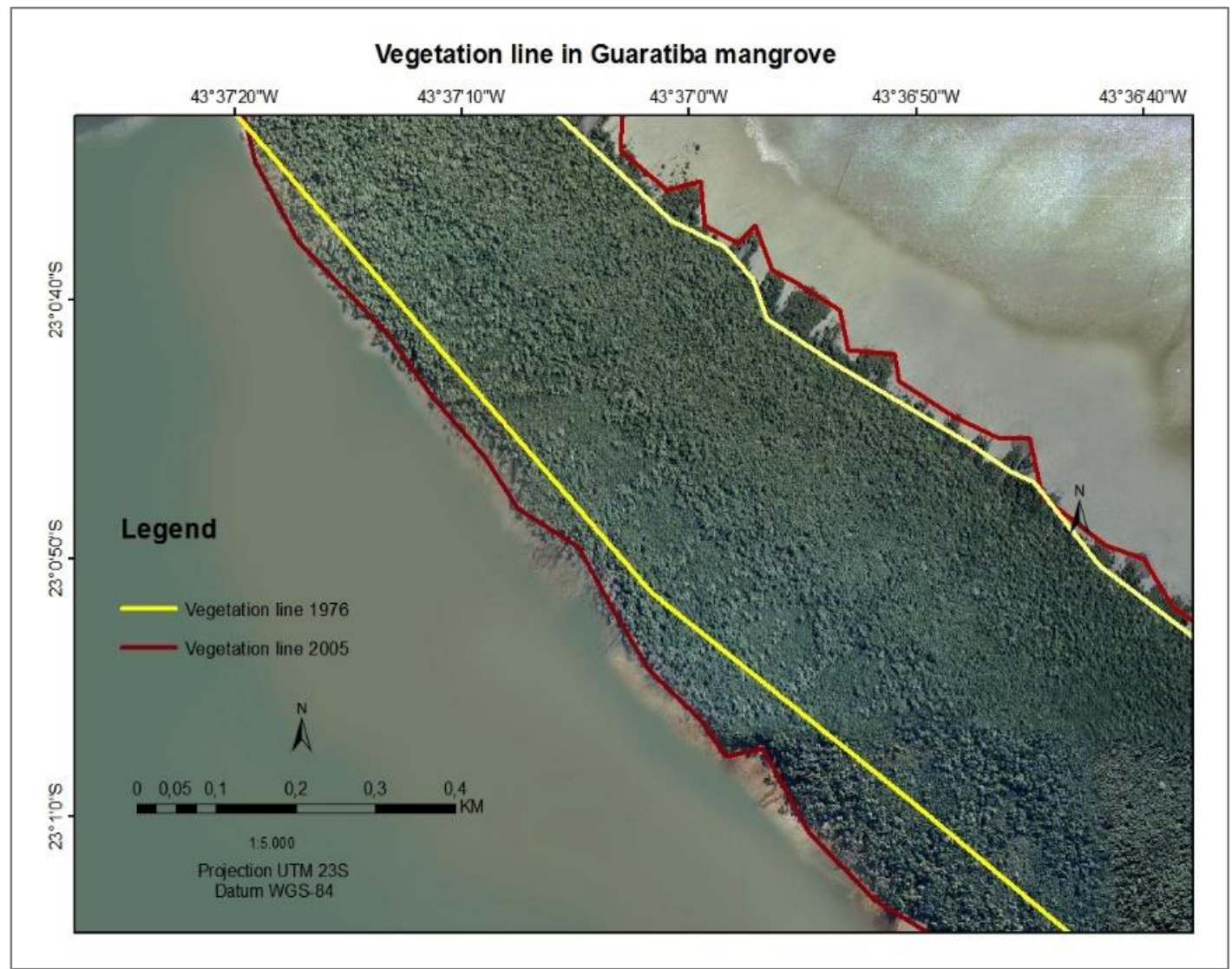

Fig. 8. Guaratiba mangrove and saltmarsh vegetation line change. Yellow line from 1976 and red line from 2005.

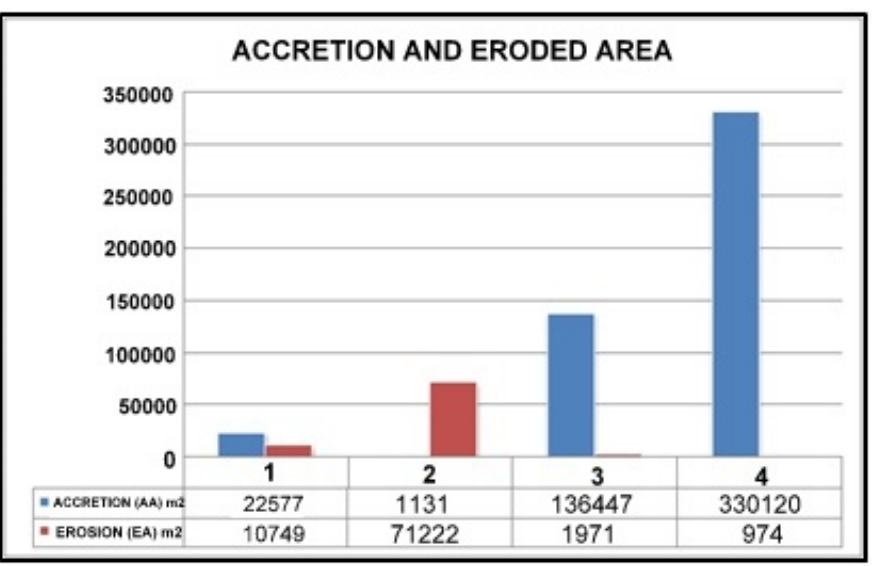

Fig. 9. Accretion and eroded areas from 1976 to 2005. Blue accretion and red erosion $\left(\mathrm{m}^{2}\right)$.

The results for the four analyzed sectors showed a total eroded area $(\mathrm{EA})$ of $\approx 84.916 \mathrm{~m}^{2}$ and a total accretion area (AA) of $\approx 490.275 \mathrm{~m}^{2}$ (Fig. 9). The SCR (Fig. 10) showed a retreat of the shoreline with greater intensity in the central stretch of Marambaia sandbank in relation to the Atlantic Ocean (sector 2) of about $8.4 \mathrm{~m}$, corresponding to an eroded area of $70.091 \mathrm{~m}^{2}$. There was a barrier migration towards Sepetiba Bay over decades, which is corroborated by studies of Oliveira et al. (2008). These results are in agreement with
Guimarães (2014) on the growth of the vegetation in marshes.

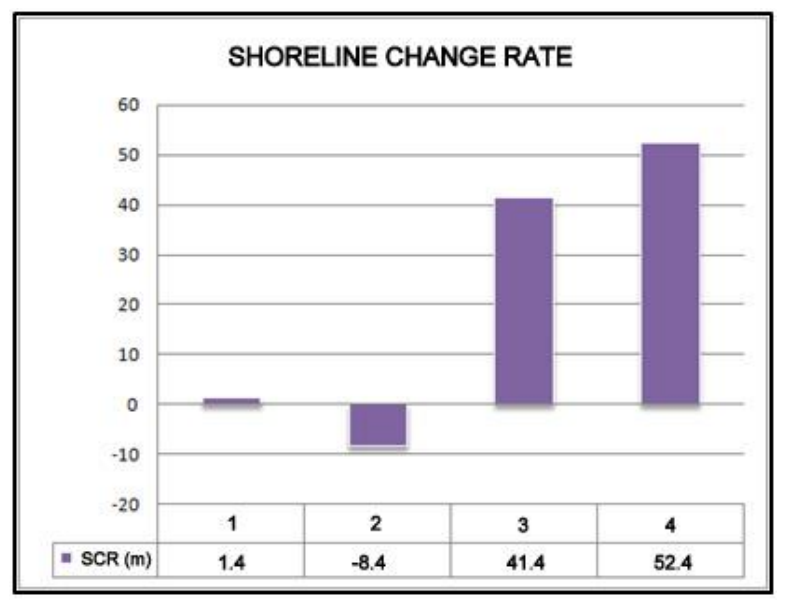

Fig. 10. Shoreline change rate from 1976 to 2005.

The sea level rise is influencing the zonation pattern in Guaratiba mangrove and the gradual advance of mangrove in the saltmarshes. In Guaratiba mangrove there are indications of erosion processes in the margin of the mangrove exposed to the bay and a growth of the mangrove for eastwards the saltmarshes and areas with dead trees as it was possible to observe in Figures 11, 12 and 13 where the saltmarsh is being colonized by mangrove trees (Guimarães, 


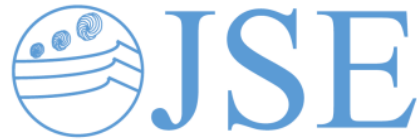

RESEARCH PAPER

2014). In Rio de Janeiro city, there are other areas with coastal erosion. Each one has its particularity, but the erosion process is similar in all of them.

The erosion in Atafona is related to natural and anthropogenic causes linked to the Paraiba do Sul River. There are records since 1975 that the erosion at south of
Paraiba do Sul River mouth has destroyed 183 buildings (Ribeiro et al., 2004). In this zone, the front erosion of the dune field displays a cliff about 3 meters high and after 5 years of surveys, the beach line fell about $37 \mathrm{~m}$, setting an average rate of decline of 7-8 m/year (Bastos and Silva, 2000).

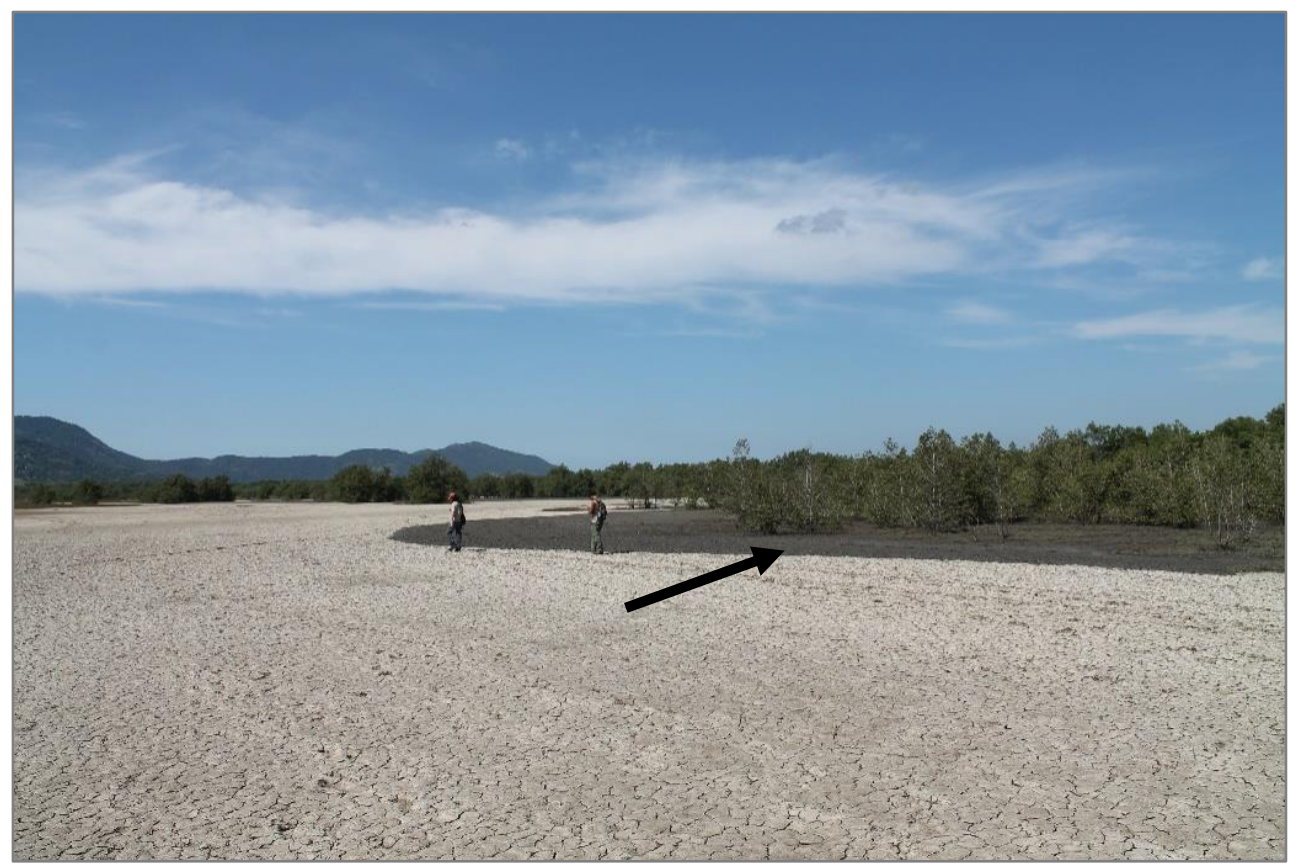

Fig. 11. Saltmarsh in Guaratiba. Indicating the gradual advance of mangrove in the saltmarshes (Date: 04/06/2016).

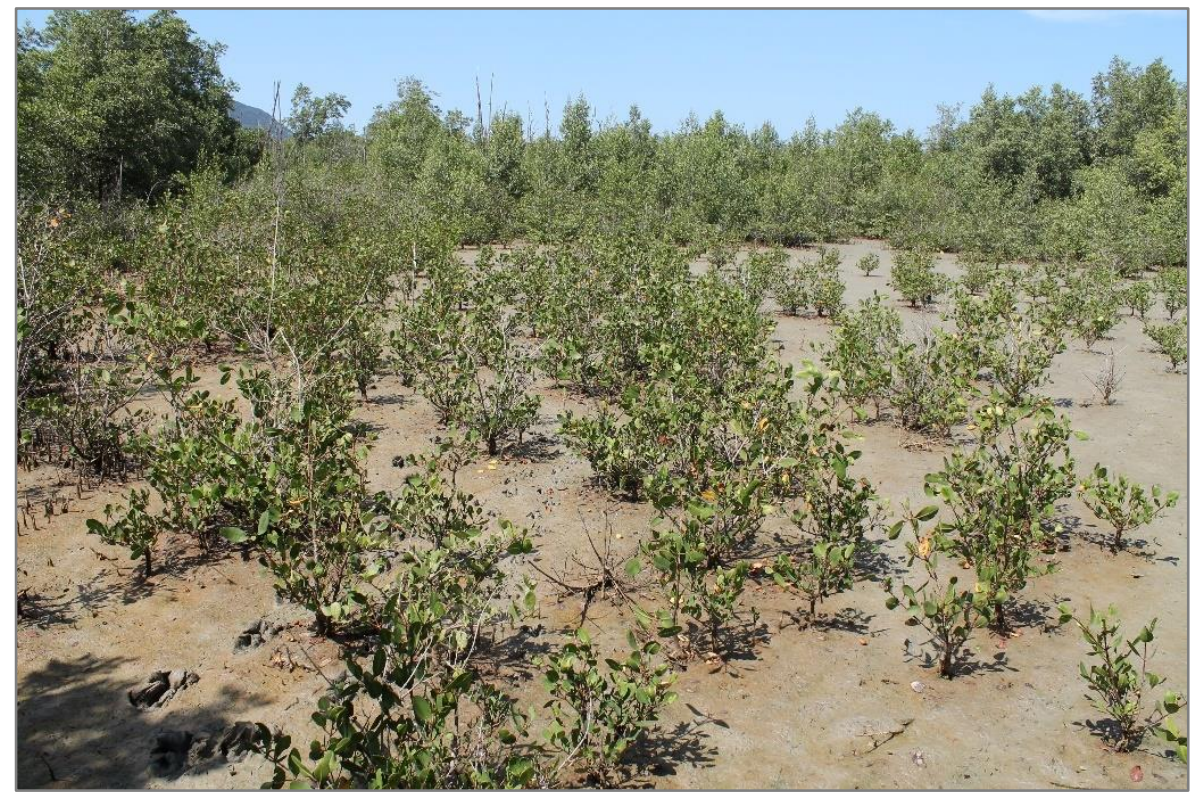

Fig. 12. Mangrove colonization in saltmarsh in the migration direction (Date: 04/06/2016) 


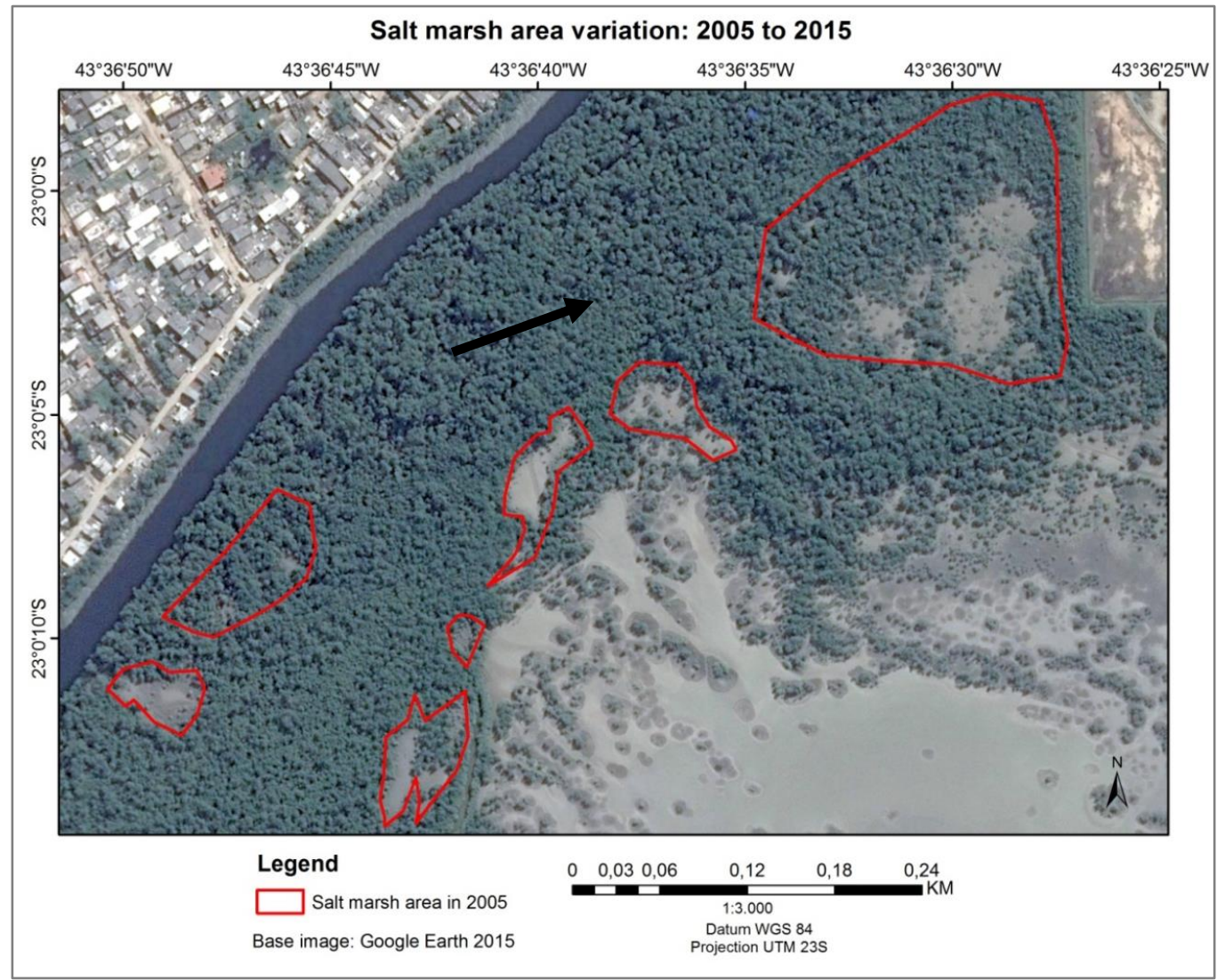

Fig. 13. Saltmarsh area variation: 2005 to 2015. The red line indicates the area in 2005 and the base picture is a Google Earth image of 2015.

The Praia das Tartarugas, in Rio das Ostras city, for example, has undergone intense and accelerated erosion. Urbanization and buildings in the backshore zone changed the sediment balance. In addition, the construction of Juturnaíba dam in São João River retained sediment upstream, which affected the sediment transport to the beaches near the mouth. This sediment deficit is causing the shoreline recession in the region (Castro et al., 2011).

Studies have shown that the mangrove, at their seaward margin, is controlled by sea level rise (Ellison, 1994). Structural gradient, sand zonation at mangroves areas associated with gradients of tidal flooding frequency and transition forests would be the pioneers of the process of mangrove species advancements on the saltflats; overtime, with the attenuation of marine influence on the substrate, the transition forests would eventually transform in what are now basin forests (Estrada et al., 2013). In Guaratiba mangrove, it is possible to observe zonation and differences in vegetation patterns due to tide change, currents activity, seasons and the mangrove dynamic over the years.

In Marambaia barrier island, the barrier migration is occurring in response to sea level rise and overwash processes that transport sediments from the barrier to the back. With the sea level rise, the sediments in the barrier are eroded and deposited in the back, causing a migration of the barrier and a search for balance (Dubois, 1976).

Oliveira et al. (2008) estimated this reduction over 29 years (1975-2004) with Landsat images, but the observed variation in $1984-2004$ period may also be influenced by great tidal influence. As the images were not necessarily acquired at the same time, the sandbank may have been imaged with different tidal height in several years, which also happens in this work despite the best resolution of the images. Oliveira et al. (2008) observed that the width of the central portion of the sand bank is reducing in size. The width reduction was of $158 \mathrm{~m}$ to $100 \mathrm{~m}$ from 1975 to 2004 and an area reduction of $0.61 \mathrm{~km}^{2}$ in 1975 to $0.55 \mathrm{~km}^{2}$ in 2004. The average width of the entire time series was $112.89 \pm 27.00 \mathrm{~m}$. According to the results of this paper and the observations of Oliveira et al. (2008), it can be stated that the area of Marambaia sand island is undergoing intense destructive erosion processes.

\section{2 - Dunes and overwash in Marambaia Barrier Island}

The results for dunes and overwash for the Marambaia sand barrier were divided in five sectors (Fig.14): A, B and C for overwash events (Fig. 15), D for parabolic dunes (Fig. 16) and $\mathrm{E}$ and $\mathrm{F}$ for barchans dunes (Fig. 17) 


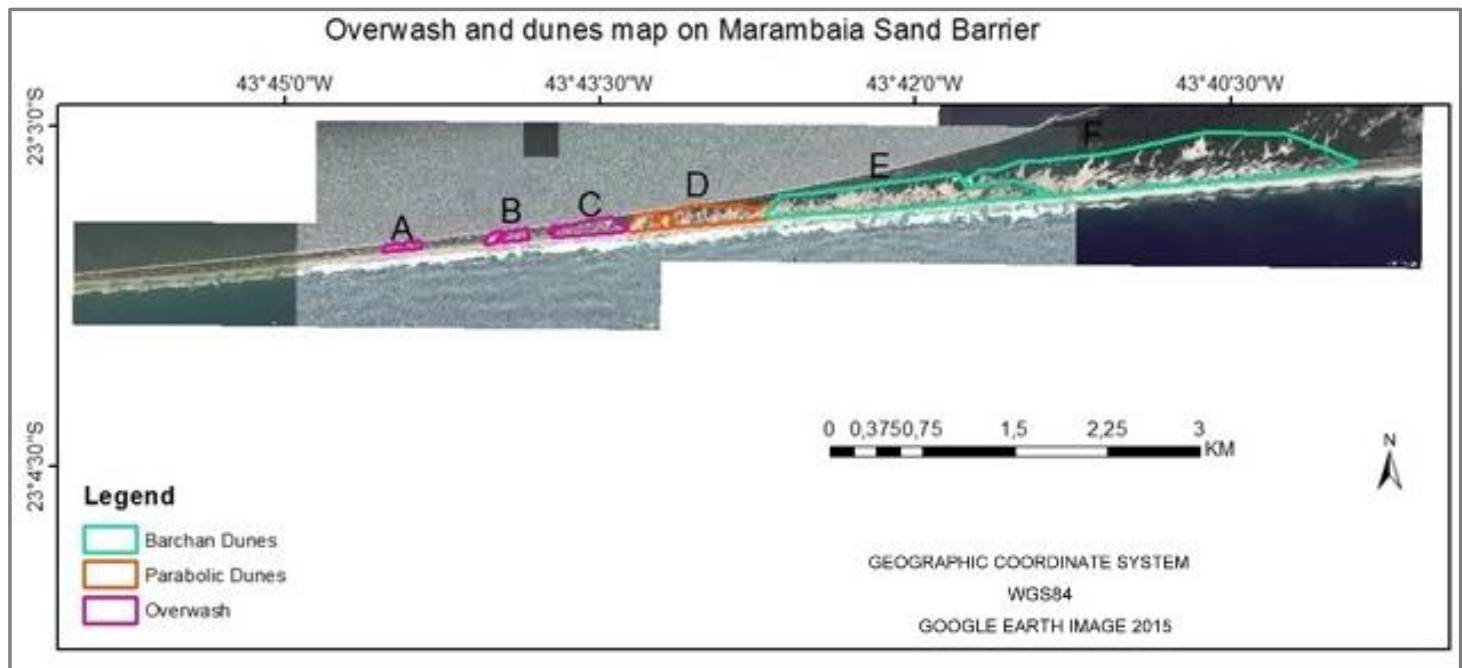

Fig. 14. Overwash and dunes map (2005).

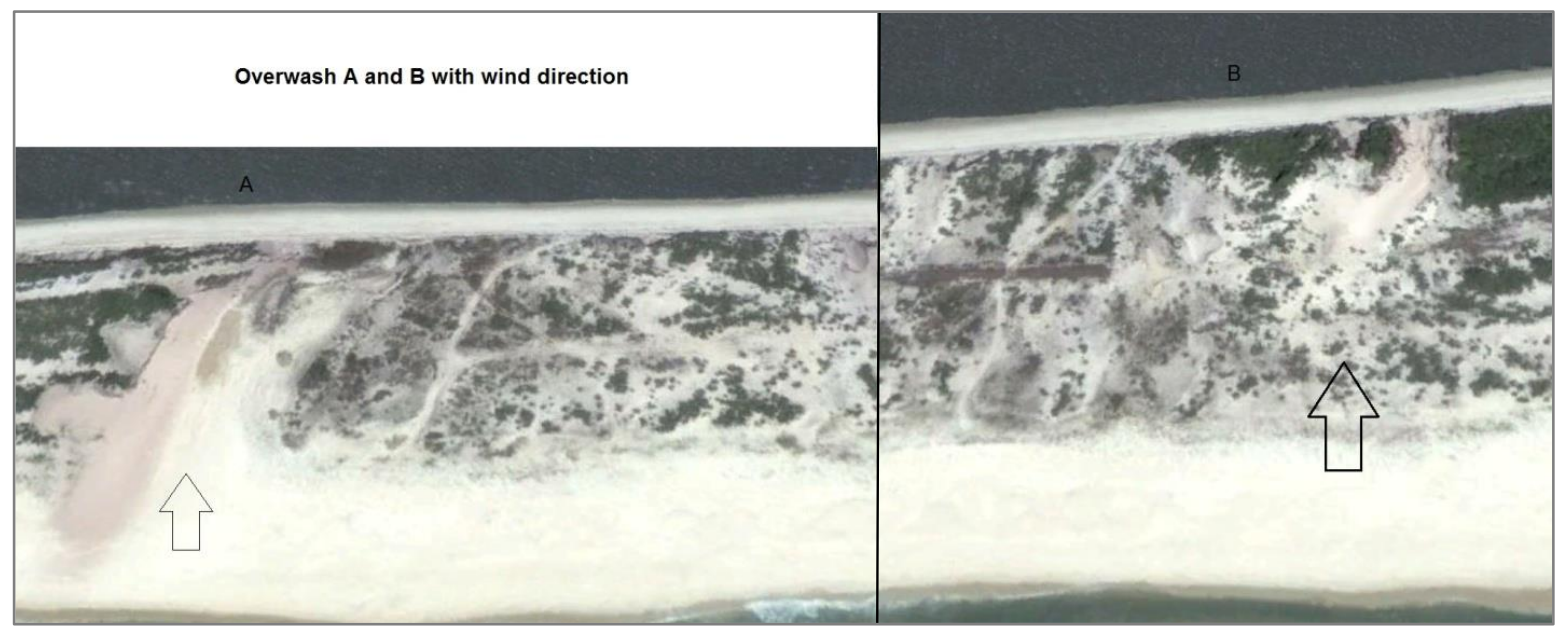

Fig. 15. Overwash in Marambaia barrier island.

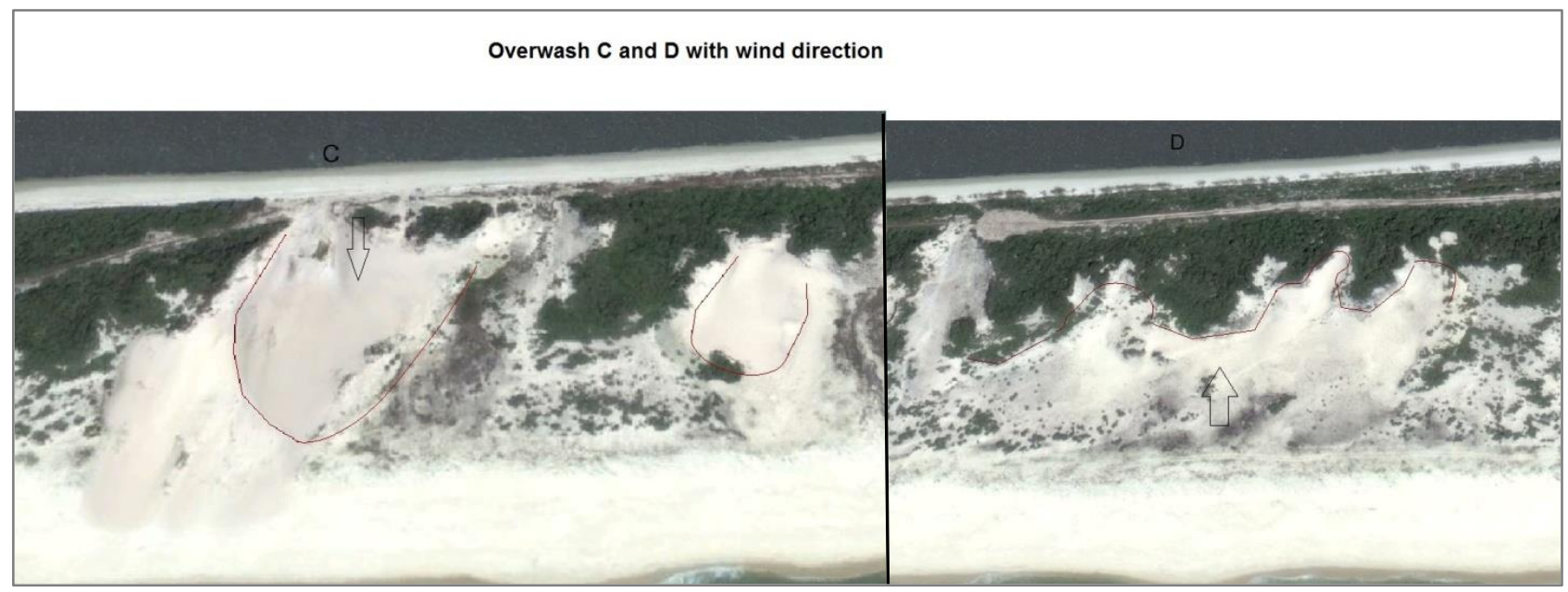

Fig. 16. Parabolic dunes in Marambaia Barrier Island. 


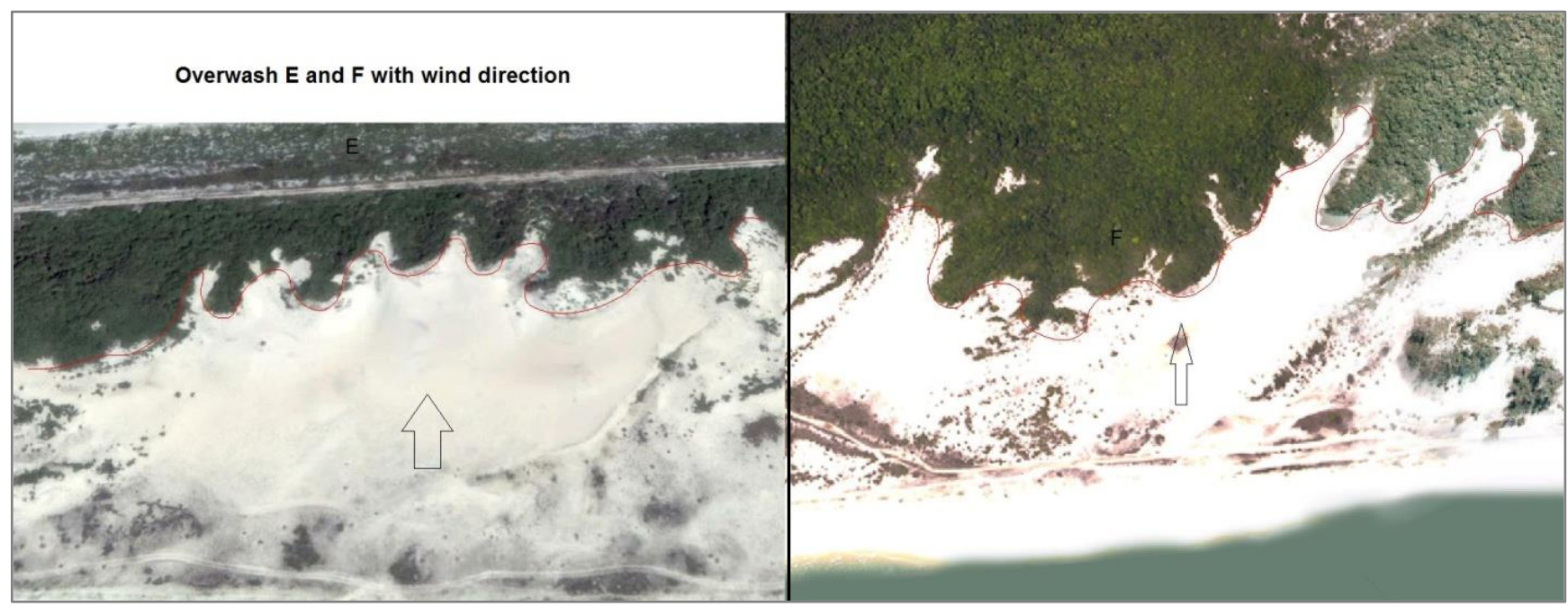

Fig. 17. Barchan dunes in Marambaia barrier island.

The sediment removed from the sandbank by the overwash and dune erosion are transported to the other side of the barrier where the internal circulation of Sepetiba Bay (Fig.17) is responsible for transporting it towards the bay and across the bay. Borges and Nittroeur (2016) identified areas in northeastern coastline of Sepetiba Bay which accumulated clayey sediments over 20 years, causing progradation of $400 \mathrm{~m}$ since 1868. In addition, the Sepetiba Beach next to the mangrove area of Guaratiba, which was mangrove in the past, was recovered with beach nourishment (Neves, 2010). However, currently, this beach was eroded again being replaced by a young mangrove.

The sediments eroded from the Sepetiba Beach, by the internal circulation of Sepetiba Bay, are being transported to south-southeast. This dynamic should explain the sedimentation in Guaratiba mangrove as shown in Fig. 18. In addition, according to Cortez and Guerra (2013), the Guaratiba channel is influenced by the hydrodynamics pattern inside the Sepetiba Bay. The most intense currents were observed during the flood tidal peak, probably by the seawater entrance into Sepetiba Bay. According to Cortez and Guerra (2013), these more active currents were the main cause for the increase of suspended particulate matter concentrations. The hypothesis is that part of the particles transported in the channel are being retained, explaining the silting over the years in the internal area of Sepatiba Bay.

According to Suguio (1999 and references herein), the sea level rise rate versus sedimentation rate may result in three situations: i) sea level rise greater than the sedimentation rate results in a marine transgression or retrogradation, with the beach migration towards the continent; ii) sea level rise equivalent to sedimentation rate corresponds to stability and; iii) sea level rise lower than sedimentation rate causes marine regression or progradation, with progradation of the shoreline. In
Marambaia barrier island the sea level rise rate is higher than the sedimentation velocity due to evidenced erosion (Oliveira et al., 2008) which is causing migration from the beach towards the continent.

The transport of sediments is important to analyze the sedimentation rate and the sea level rise in relation to the shoreline change. In Marambaia barrier island there are sediment losses from overwash, dune erosion, wind transport, longshore transport in Sepetiba Bay and in the Atlantic Ocean and Sepetiba Bay dredging (Fig.19). In Guaratiba mangrove the sediment loss is related to the tidal flux and also dredging activities in the Sepetiba Bay. The sediment gain also includes the tidal flux, river discharge and the longshore transport from the Sepetiba Bay (Fig.20).

Rosati et al. (2010) developed a model of evolution of sandy barrier islands covering years to decades due to coastal erosion, overwash and migration. Results indicated that the barrier island are subject to: i) reduction of dune elevation; ii) volume changes in the outer region of the barrier; iii) increased overwash and; iv) migration when the dunes reach a small critical elevation. In Marambaia barrier island the sea adjustments contribute to the migration and transport of sediment to reverse the barrier, with evidence of erosion and reducing of the barrier over the years.

Snoussi et al. (2009) analyzed the impact of the mean sea level rise in Tangier Bay (Morocco), and found three beaches with greater vulnerability to coastal erosion. The vulnerability is not related only to the sediment regime in the bay but indicates an erosive trend in the southeastern part of the past two decades, but also due to lack of sandy sediments. Nowadays, hotels were built a few meters from the shoreline and therefore dunes were destroyed, which affect an adjustment from the beach to a new profile of sea level rising. This situation does not occur in Marambaia barrier as in the area of dunes there is no human intervention. 


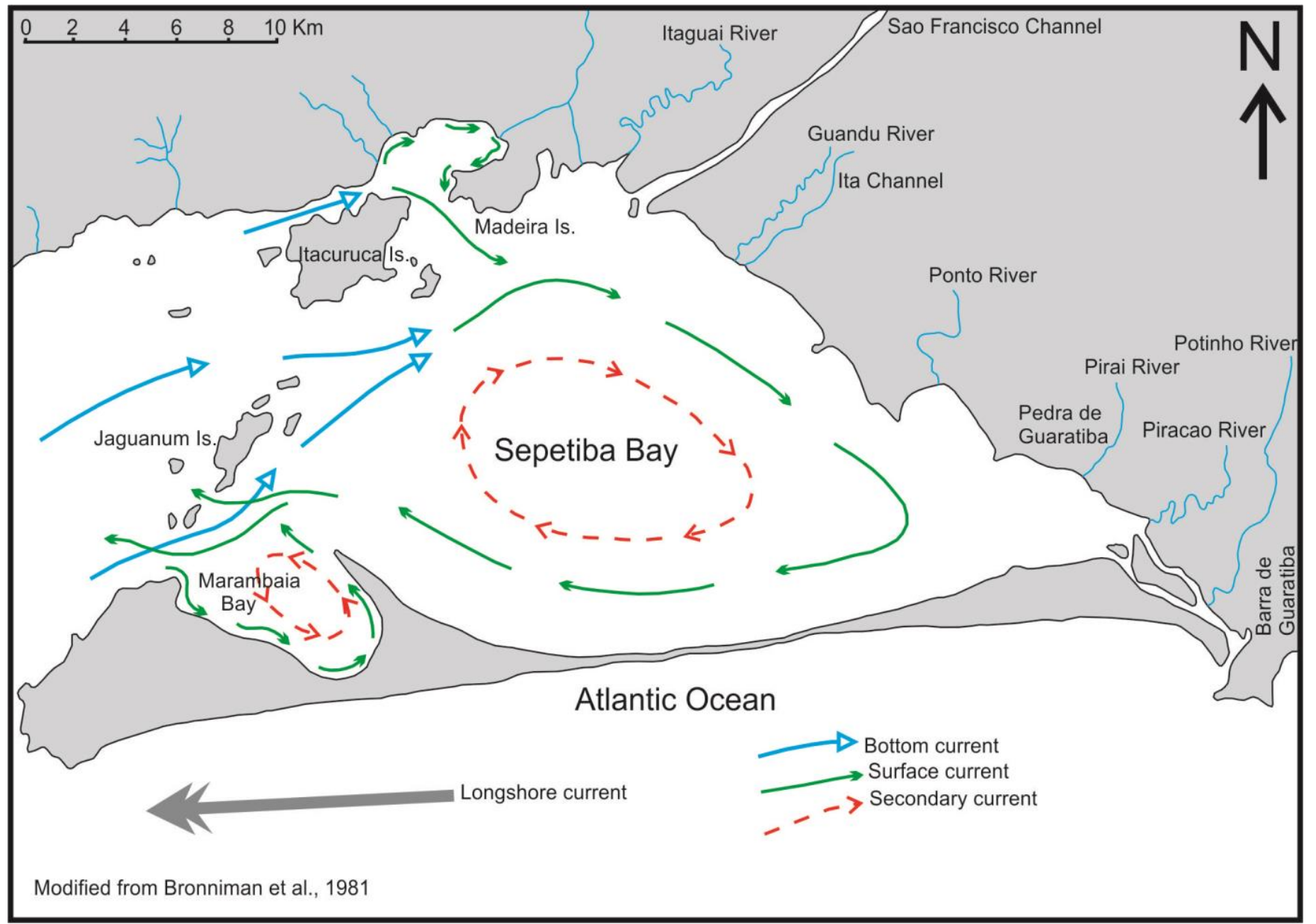

Fig. 18. Generalized current system in Sepetiba Bay. The cold and dense water enters the bay as bottom currents (Borges and Nittroeur, 2016).

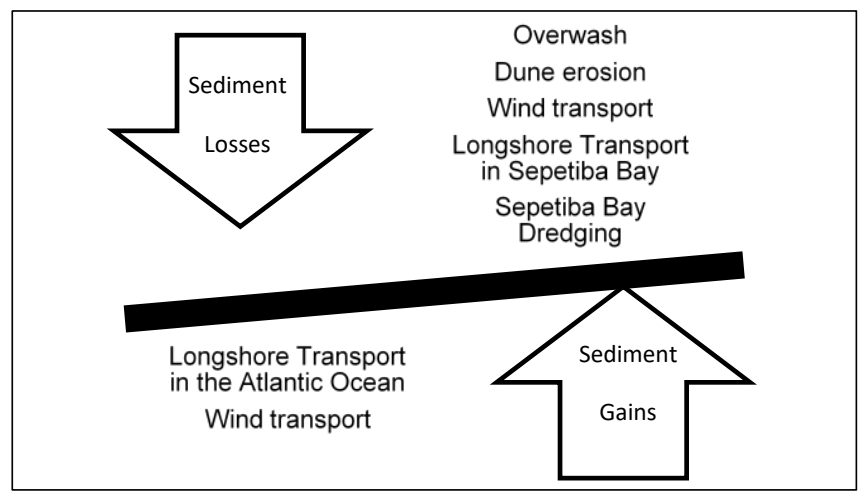

Fig. 19. Sediment transport flux in Marambaia barrier island.

The vulnerability of the sandbank is given from the increase in overwash events, destruction or migration of the dunes and a possible disruption of the central part of the barrier (Williams, 2013), which would cause a change in the internal circulation creating a new communication of Sepetiba Bay and the ocean, changing the bay internal circulation and consequently the present ecosystems.

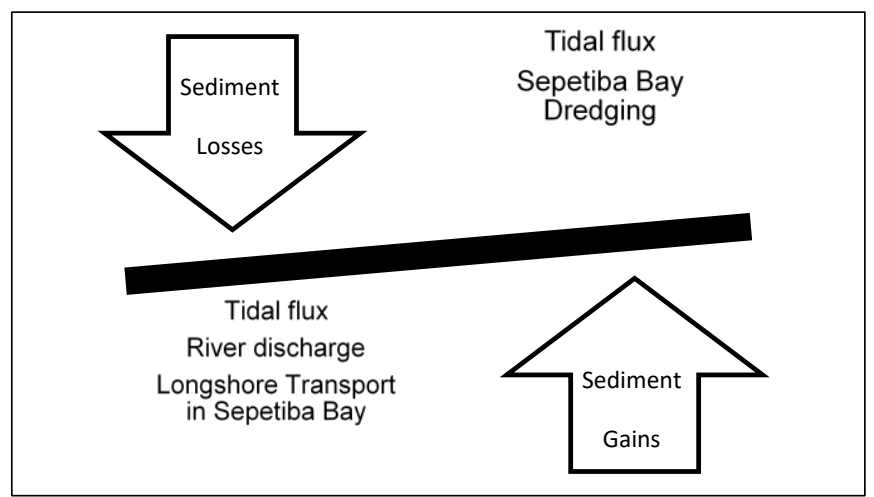

Fig. 20. Sediments transport flux in Guaratiba mangrove.

\section{Conclusion}

Coastal land form is not simply inundated as sea level rise but the impacts vary over time and location, and are determined by geophysical processes and geologic characteristics. For barrier islands, these changes may result in increased landward migration, geomorphic change such as 
reduction in size or segmentation, or in extreme cases, drowning of the barrier island.

The Marambaia barrier island migration and erosion is related to a lower sedimentation rate and sea level rise. This effect is happening in many shorelines around the world. The increase of the vegetation area in the Sepetiba Bay shoreline, at the Guaratiba mangrove region, can be explained by a higher sedimentation rate than sea level rise. But, the vegetation growth in the saltmarsh suggests a landward migration, which is a consequence of sea level rise.

If this trend remains, it is possible a disruption in the central area of the Marambaia Barrier Island, which will create a new communication to the Sepetiba Bay and the ocean, changing the bay internal circulation and consequently the present ecosystems and the reduction or disappearance of the mangrove due to anthropic pressure and the physical barrier in one side and the sea level rise in the other.

\section{Acknowledgment}

The authors thank CAPES for the fellow ship, the support given by the Universidade Federal Fluminense and the Instituto Estatudal do Ambiente - INEA.

\section{References}

Almeida, H.R.R.C., Cruz, R.S., Lima, A. H. A, Luz, V.T., 2013. Avaliação das taxas de variação da linha de costa através de imagens orbitais e levantamento GPS na praia de riacho doce Maceió - AL. Anais XVI Simpósio Brasileiro de Sensoriamento Remoto, INPE, 5389-5396.

Almeida, J.R., Suguio, K., 2012. Potencialidade geoturística das dunas eólicas da Ilha Comprida - São Paulo, UNESP, Geociências 31 (3), 473-484.

Bastos, A.C., Silva, C.G., 2000. Caracterização morfodinâmica do litoral Norte Fluminense, RJ, Brasil. Revista Brasileira de Oceanogria 48, (1), 41-60.

Bastos, B.C., Bassani, C., 2012. A questão da expansão portuária como solução para o desenvolvimento econômico: o caso das dragagens e os impactos ambientais na baía de Sepetiba. Simpósio de Excelência em Gestão e Tecnologia, p. 17.

Bird, E., 2008. Coastal geomorphology an introduction. 2 ed. England: John Wiley \& Sons. 411 p.

Bird, E.C.F., 1996. Coastal erosion and rising sea level. In: Millimann, J.D., Haq, B.U. (Eds.), Sea Level Rise and Coastal Subsidence, 87-103.

Borges, H.V., Nittroeur, C.A., 2016. Sediment accumulation in Sepetiba bay (Brazil) during the Holocene: a reflex of the human influence. Journal of Sedimentary Environments 1 (1), 96-112. htps://doi.org/10.12957/jse.2016.21868

Brantley, S.T, Bissett, S.N., Young, D.R., Wolner, C.W.V., Moore, L.J., 2014. Barrier island morphology and sediment characteristics affect the recovery of dune building grasses following storm-induced overwash. Plos One 9 (8), e104747. https://doi.org/10.1371/journal.pone.0104747

Brönnimann, P., Moura, J.A., Dias-Brito, D., 1981. Ecologia dos foraminíferos e microrganismos associados da área de
RESEARCH PAPER

Guaratiba/Sepetiba: Modelo ambiental e sua aplicação na pesquisa de hidrocarbonetos. Relatório 3549. PETROBRAS.

Bush, D.M., Neal, W.J., Young, R.S, Pilkey, O.H., 1999. Utilization of geoindicators for rapid assessment of coastal-hazard risk and mitigation. Ocean and Coastal Management 42, 647-670. https://doi.org/10.1016/S0964-5691(99)00027-7

Castro, J.W.A., Fernandes. D., Dias, F.F., 2011. Monitoramento do processo de erosão costeirana Praia das Tartarugas, Rio das Ostras - Estado do Rio de Janeiro / Brasil: Aplicação de metodologia quantitativa. Revista de Gestão Costeira Integrada / Journal of Integrated Coastal Zone Management 11 (3), 355368.

Church, J.A, Clark, P.U., Cazenave, A., Gregory, J.M., Jevrejeva, S., Levermann, A., Merrifield, M.A., Milne, G.A., Nerem, R.S., Nunn, P.D., Payne, A.J., Pfeffer, W.T., Stammer, D., Unnikrishnan, A.S., 2013. Sea Level Change. In: Stocker, T.F., Qin, D., Plattner, G.K., Tignor, M., Allen, S.K., Boschung, J., Nauels, A, Xia, Y., Bex, V., Midgley, P.M. (eds.), Climate Change 2013, The Physical Science Basis. Contribution of Working Group I to the Fifth Assessment Report of the Intergovernmental Panel on Climate Change. Cambridge University Press, Cambridge, United Kingdom and New York, NY, USA, pp. 1137-1216.

Cortez, R.H.C, Guerra, J.V. 2013. Observação da tensão cisalhante e transporte de material particulado em suspensão em um canal de maré - Barra de Guaratiba, RJ. X Simpósio sobre Ondas, Marés, Engenharia Oceânica e Oceanografia por Satélite OMAR-SAT, 5p.

Cozannet, G. Le, Garcin, M., Yates, M., Idier, D., Meyssignac, B., 2014. Approaches to evaluate the recent impacts of sea-level rise on shoreline changes. Earth-Science Reviews 138, 47-60.

Davidson-Arnott, R., 2010. Introduction to coastal process and geomorphology. New York: Cambridge University Press. 442 p.

Dubois, R.N., 1976. Nearshore evidence in support of the Brunn rule on shore erosion. Journal of Geology 84, 485-491.

Díaz Morales, S.J., Guerra, J.V., Nunes, M.A.S, Souza, A.M., Geraldes, M.C., 2019. Evaluation of the environmental state of the western sector of Sepetiba Bay (SE Brazil): trace metal contamination. Journal of Sedimentary Environments, 4 (2): 174-188. https://doi.org/10.12957/jse.2019.43764

Ellison, J.C., 1994. Climate change and seal level rise impacts on mangrove ecosystems. In: Pernetta, J., Leemans, R., Elder, D., Humphrey, S. (Eds), Impacts of climate change on ecosystems and species: marine and costal ecosystems. A marine conservation and development report, IUCN, Glab, Switzerland, pp. 11-30.

Estrada, B., Aroca, R., Barea, J.M., Ruiz-Lozano, J.M., 2013. Native arbuscular mycorrhizal fungi isolated from a saline habitat improved maize antioxidant systems and plant tolerance to salinity. Plant Science 201, 42-51. http://dx.doi.org/10.1016/j.jaridenv.2013.05.019

Figlus, J., Kobayashi, N., Gralher, C., Iranzo, V., 2011. Wave Overtopping and Overwash of Dunes. Journal of Waterway, Port, Coastal, and Ocean Engineering 37 (1), 26-33. https://doi.org/10.1061/(ASCE)WW.1943-5460.0000060

Freudenrich, C., 2001. How Barrier Islands Work. HowStuffWorks.com. Available in: $<$ https://science.howstuffworks.com/environmental/conservatio $\mathrm{n} /$ issues/barrier-island.htm> (Accessed on 3 August 2019) 
Garcin, M., Yates, M., Le Cozannet, G., Walker, P., Donato, V., 2011. Sea level rise and coastal morphological changes on tropical islands: example from New Caledonia and French Polynesia (SW Pacific). Geophysical Research Abstracts 13, 3504.

Gornitz, V., 1991. Global coastal hazards from future sea level rise. Palaeogeography, Palaeoclimatology, Palaeoecology (Global and Planetary Change Section) 89, 379-398. https://doi.org/10.1016/0031-0182(91)90173-O

Guimarães, M., 2014. Rede de proteção: manguezais ganham importância diante de alterações no clima. Revista Pesquisa Fapesp 216, 36-41.

Gutierrez, B.T, Williams, S.J, Thieler, E.R., 2007. Potential for Shoreline Changes Due to Sea-level Rise Along the U.S. MidAtlantic Region. U.S. Geological Survey Open File Report 2007-1278. https://doi.org/10.3133/ofr20071278

INEA. Informações úteis. 2015. Available in: <http://www.inea.ri.gov.br/Portal/Agendas/biodiversidadee areasprotegidas/UnidadesdeConservacao/INEA_008603\#/I nformaçõesúteis $>$ (Accessed on 3 August 2019)

Kjerfve, B., Macintosh, D.J., 1997. The impact of climatic change on mangrove ecosystems. Mangrove ecosystem studies in Latin America and Africa. International Society for Mangrove Ecosystems, ISME-UNESCO, 1-7.

Komar, P. D., 1996. The budget of littoral sediments - concepts and applications. Shore and Beach 64, 18-26.

Matias, A., Vila-Concejo, A., Ferreira, Ó., Morris, B., Dias, J., 2009. Sediment Dynamics of Barriers with Frequent Overwash. Journal of Coastal Research 25 (3), 768-780. https://doi.org/10.2112/08-1032.1

Neves, C., Muehe, D., 2008. Vulnerabilidade, impactos e adaptação a mudanças do clima: a zona costeira. In: Parcerias Estratégicas Brasília 27, 217-295.

Neves, M., 2010. Minha praia de volta. Odebrech Informa, 149 p.

Nicholls, R.J., Wong, P.P., Burkett, V.R., Codignotto, J.O., Hay, J.E., McLean, R.F., Ragoonaden, S., Woodroffe, C.D., 2007. Coastal Systems and low-lying areas. In: Parry, M.L, Canziani, O.F., Palutikof, J.P., Van Der Linden, P.J., Hanson, C.E. (eds), Climate Change 2007: Impacts, Adaptation and Vulnerability. Contribution of Working Group II to the Fourth Assessment Report of the Intergovernmental Panel on Climate Change. Cambridge University Press, Cambridge, UK, pp. 315-356.

NOAA (National Oceanic and Atmospheric Administration). Beach Nourishment: A Guide for Local Government Officials. 2016. Available in: https://coast.noaa.gov/archived/ beachnourishment/html/ geo/budgets.htm\#top (Accessed on 3 August 2019)

NOAA (National Oceanic and Atmospheric Administration). Tendência relativa do nível do mar 874-092 Ilha Fiscal, Brasil, 2019. In: Tides \& Currents. Available in: < https://tidesandcurrents.noaa.gov/sltrends/sltrends_station.s html?id $=874-092>$ (Accessed on 3 August 2019)

Oliveira, F.S.C., Kampel, M., Amaral, S., 2008. Multitemporal assessment of the geomorphologic evolution of the Restinga of Marambaia, Rio de Janeiro, Brazil. International Journal of Remote Sensing 29, 5585-5594. https://doi.org/10.1080/ 01431160802061696
Ponçano, W.L., Fulfaro, J.V., 1976. Sedimentação atual na Baía de Sepetiba, Estado do Rio de Janeiro: contribuição à avaliação de viabilidade geotécnica da implantação de um porto. In: Anais do I Congresso Brasileiro de Engenharia, pp. 111-126.

Portos Rio, 2010. Gerenciamento de dragagem garante integridade da Baía de Sepetiba. Avaiable in: https://portogente.com.br/artigos/77636-gerenciamento-dadragagem-garante-integridade-da-baia-de-sepetiba (Acessed on 3 August 2019).

Rodrigues, B.A., Matias, A, Ferreira, Ó., 2012. Overwash hazard assessment. Geologica Acta 10 (4), 427-437. https://doi.org/10.1344/105.000001743

Rosati, J.D., Dean, R.G., Gregory, W.S., 2010. A cross-shore model of barrier island migration over a compressible substrate. Marine Geology 271, 1-16. https://doi.org/10.1016/j.margeo.2010.01.005

Snoussi, M., Ouchani, T., Khouakhi, A., Niang-Diop, I., 2009. Impacts of sea-level rise on the Moroccan coastal zona: Quantifying coastal erosion and flooding in the Tangier Bay. Geomorphology 107, 32-40. https://doi.org/10.1016/ j.geomorph.2006.07.043

Souza, C.R. de G., 2009. A Erosão nas Praias do Estado São Paulo: Causas, Conseqüências, Indicadores de Monitoramento e Risco. In: Bononi, V.L.R., Santos Junior, N.A. (Org.), Memórias do Conselho Cientifico da Secretaria do Meio Ambiente: A Síntese de Um Ano de Conhecimento Acumulado, pp.48-69, Instituto de Botânica - Secretaria do Meio Ambiente do Estado de São Paulo, São Paulo, SP, Brasil. (ISBN 978-857523-025-1).

Stive, M.J.F., Aarninkhof, S.G.J., Hamm, L., Hanson, H., Larson, M., Wijinberg, K.M., Nicholls, R.J., Capobianco, M., 2002. Variability of shore and shoreline evolution. Coastal Engineering 47, 211-235. https://doi.org/10.1016/S03783839(02)00126-6

Stive, M.J.F., 2004. How important is global warming for coastal erosion? An editorial comment. Climatic Change. 64, 1-2. https://doi.org/10.1023/B:CLIM.0000024785.91858.1d

Suguio, K., 1999. Geologia do Quaternário e Mudanças Ambientais (Passado + Presente $=$ Futuro?). Paulo's Editora, 366 p.

van Rijn, L.C., 2011. Coastal erosion and control. Ocean and Coastal Management. 54, 867-887. https://doi.org/10.1016/j.ocecoaman.2011.05.004

Vargas, C.I.C., Oliveira, F.S.B.F., Oliveira, A., Charneca, N., 2008. Análise da Vulnerabilidade de uma Praia Estuarina à Inundação: aplicação à Restinga do Alfeite (Estuário do Tejo). Revista da Gestão Costeira Integrada 8 (1), 25-43.

Williams, S.J., 2013. Sea-Level Rise Implications for Coastal Regions. Journal of Coastal Research: Special Issue 63 Understanding and Predicting Change in the Coastal Ecosystems of the Northern Gulf of Mexico: pp. $184-196$. https://doi.org/10.2112/SI63-015.1

Zhang, K., Douglas, B.C., Leatherman, S.P., 2004. Global warming and coastal erosion. Climatic Change 64, 41-58. https://doi.org/10.1023/B:CLIM.0000024690.32682.48 